\title{
Resilience, Adaptation and Expected Support for Food Security among the Malaysian
}

East Coast Poor Households

\author{
Md. Mahmudul Alam* \\ Senior Lecturer \\ School of Economics, Finance \& Banking (SEFB) \\ Universiti Utara Malaysia (UUM) \\ Sintok, Kedah, Malaysia \\ Email: rony000@gmail.com \\ Mobile: +60182467050 \\ Chamhuri Siwar \\ Emeritus Professor \\ Institute for Environment and Development (LESTARI) \\ National University of Malaysia (UKM) \\ 43600 UKM Bangi, Selangor Darul Ehsan, Malaysia \\ E-mail: csiwar@ukm.my
}

\author{
Abu N.M. Wahid \\ Professor \\ Department of Economics and Finance \\ Tennessee State University \\ Nashville, Tennessee, USA \\ E-mail: awahid@tnstate.edu
}

\section{Citation Reference:}

Alam, M.M., Siwar, C., \& Wahid, A.N.M. (2018). Resilience, Adaptation and Expected Support for Food Security among the Malaysian East Coast Poor Households. Management of Environmental Quality, 29(5), 877-902. (online) HTTPS://DOI.ORG/10.1108/MEQ-01-2018-0013

This is a pre-publication copy.

The published article is copyrighted by the publisher of the journal.

\footnotetext{
* Corresponding author
} 


\section{Biographical notes:}

Md. Mahmudul Alam is a Senior Lecturer of Finance at Universiti Utara Malaysia (UUM). $\mathrm{He}$ is also affiliated with Accounting Research Institutes (ARI) at University Technology MARA (UiTM) in Malaysia and International Islamic University Chittagong (IIUC) in Bangladesh as a Research Associate. He obtained Ph.D. and Master's degrees in Environment and Development (Fin. \& Econ.) from National University of Malaysia (UKM) and Bachelor (Hons) degree in Business Administration (Fin. \& Econ.) from North South University (NSU) in Bangladesh. He has a good number of publications including 100+ articles in refereed journals and five books/ monographs. He has presented $60+$ articles in international conferences. He is recognized as one of the "Top Bangladesh Development Researchers of the Millennium" by BDRC. His research areas include sustainable development, ecological economics, Islamic economics, governance, finance \& investment, etc.

Abu N. M. Wahid is a Professor of Economics at Tennessee State University and the Managing Editor of the Journal of Developing Areas. Up until now, he has produced SIX books as author, editor, and co-editor and has made about 60 publications in the form of refereed journal articles and book chapters. Professor Wahid received many research grants including the Fulbright Research Fellowship in 1997. He is the recipient of the faculty excellence awards for research at Tennessee State University and Eastern Illinois University. Professor Wahid has visited academic institutions in about 20 different countries to give public lectures and seminar presentations. Since 2008, he delivered 4 Keynote addresses in international conferences held in Malaysia, the Philippines, and Taiwan. He read and reviewed $20 \mathrm{Ph}$.D. dissertations as external examiner for various reputed universities around the world.

Chamhuri Siwar is an Emeritus Professor and Principal Research Fellow at the Institute for Environment and Development (LESTARI), National University of Malaysia (UKM). He has been serving UKM as a lecturer, head of department, and research fellow for more than 40 years. He graduated from UKM, Leeds and Iowa State University in the areas of Applied Economics, Agriculture and Resource Economics. He has successfully supervised 40 Ph.D. and 20 Master's students. He has been external examiners of numerous graduate students in Malaysia and abroad. He has wide publications in reputed international and national journals. His area of specialization includes Agricultural and Resource Economics, Rural Economics, Environmental Economics, Poverty and Income Distribution, Sustainable Economics, Socioeconomics Impact, and Sustainable Livelihood Studies. 


\title{
Resilience, Adaptation and Expected Support for Food Security among the Malaysian East Coast Poor Households
}

\begin{abstract}
Purpose: Sustainable food security at the household level is one of the emerging issues for all nations. It is expected that the patterns of household resilience factors and adaptation practices have a strong linkage with household food security. The aim of this study was to seek an effective technique of adaptation for food security and the required types of support for adaptation to food insecurity among the poor and low income households in Malaysia.

Design/methodology/approach: This study was based on primary data that were collected in Jul-Oct 2012 through a questionnaire survey among 460 poor and low income households from the Pahang, Kelantan, and Terengganu states of Malaysia. The samples were selected from E-Kasih poor household database based on a two-stage cluster random sampling technique. The study considered household food security as household food availability and food accessibility, and ran ordinal regressions to find out the linkages of household food security with household resilience factors, adaptation practices, and expected support for adaptation to food security.

Findings: The study concludes that several resilience factors and adaptation practices were statistically significant to household food security, and several external supports were statistically and significantly needed to ensure household food security. Therefore, to ensure sustainable household food security in Malaysia, the food security programs needs to be integrated with Sustainable Development Goals (SDGs) and climatic changes adaptation programs, and the involvement of relevant stakeholders are crucial.

Originality/value: This study is a pioneer work based on primary data that empirically measured the linkages of household food security with household resilience factors, adaptation practices, and expected support for adaptation to food security in Malaysia. This study also discussed some issues related to the climate change linkage, which would help future climate change research. The findings of the study will be beneficial for all the stakeholders, including policy makers related to the food security and climate change adaptation.
\end{abstract}


Keywords: Climate Change; Household Food Security; Household Food Insecurity Access (HFIA); Adaptation; Resilience; Poverty; Ordinal Regression; Sustainable Development Goals (SDG); Malaysia

JEL Codes: I32, Q54, P48

\section{Introduction}

Food security is a critical aspect of individual and household wellbeing regardless of whether it is viewed globally, locally, or communally/. Hunger and food insecurity are detrimental to the basic rights of a human being and are a prelude to the problems of health, nutrition, and development. The main challenges to food security are political, economic, social, infrastructural, demographic, livelihood strategies, etc. (Frankenberge, 1992; Cristofar \& Basiotis, 1992; Nyariki \& Wiggins, 1997; Smith, 1998; Lovendal \& Knowles, 2006; FAO, 2003, 2008; Alam et al., 2016b ). However, now-a-days, changes in the climatic factors and their outcomes, such as natural calamities, are also considered another challenge to sustainable food security (Alam et al., 2016b, 2017).

People facing food insecurity are mostly from the poor communities who are also vulnerable to the potential effects of climate changes and have the least capability to adapt to these situations (FAO, 2009; Siwar et al., 2009). Moreover, a study from FAO (2011) states that, the major portion of poor people's income is spent on food. On the other hand, there are still 836 million people in the world living in extreme poverty (United Nations, 2015), and at least 70 percent of the very poor live in rural areas; most of them depend partly or completely on agriculture for their livelihoods (IFAD, 2011). Since, FAO (2016) estimates that, to satisfy the growing demand driven by population growth and diet changes, food production will have to be increased by at least 60 percent in the next decades. However, world hunger is on the rise; the estimated number of undernourished people has increased from 777 million in 2015 to 815 million in 2016 (FAO, 2017). Poor people who suffer from food insecurity and low income households are economically deprived groups in the society as well as frequently more exposed to natural disasters; in addition, they are exposed to highly reliant resources that are climate-sensitive, and they have limited resources in terms of technology and economy. Their adaptability to climatic and non-climatic food insecurity is dependent on adaptation strategies that are based on socioeconomic and cultural factors, such as household 
composition, gender, and household asset distribution, and from external institutions (FAO, 2006).

Strategies for adaptation to climate changes to establish food security could be planned or autonomous. Planned adaptation includes the growth in adaptive capability by utilizing policies and institutions to set up or strengthen favorable situations for effective adaptation and new technologies and infrastructure investment (Yohe et al., 2007). Autonomous adaptation involves the continuous implementation of current technology, knowledge and adaptability in responding to the level of food insecurity (Easterling et al., 2007). In most cases, autonomous adaptations are used by households, but they are insufficient to deal with food insecurity; as a result, planned, strategic measures are required.

Strategies for adaptation to climatic or non-climatic food insecurity at household level are complicated and frequently limited. According to Maxwell et al. (1999), in urban and rural settings, there are four categories of coping strategies linked to food-search behaviors, dietary change, household rationing, and structure that are normal methods adopted by households facing food insufficiency. However, but the particular coping strategy inside each category might differ across various settings. Based on various environmental situations (such as rural versus urban culture, cost of living, employment status of women and education), the low-income urban households may use various specific mechanisms to cope with food insufficiency and income compared to rural households. Likewise, Davies (1996) points out that different features of coping behaviors (sequence of importance or intensity, definition, short-term and long-term changes) might vary between locations (e.g., rural versus urban) and inside a particular location (agricultural versus fishing community in rural areas).

According to Shariff and Khor (2008), low-income rural households utilize foodrelated coping strategies (borrowing money to buy food and cook whatever food is available at home) when they face food insecurity. Dore et al. (2003) suggested that using cheaper food and eating at home were common coping strategies among Russian low-income households to protect the children's dietary intakes. Reduced quantity and frequency of food intake, affected diet and food quality; food preference and food substitution, food store changes, borrowing food or money and sale of assets were the strategies used by Javanese families during the economic crisis in 1998 in Indonesia (Studdert et al., 2001). Diversifying or changing livelihood is also utilized for adaptation, such as via migration to search for 
additional income sources or in some cases forcible sales of assets (Devereux, 2001; Ellis, 1998). Having access to healthcare is also a major concern in managing and controlling diseases related to food security (Makinen et al., 2000).

Malaysia is a fast growing developing country. Therefore, there are scopes of frequent changes in the macro variables and policies that would affect food security (Alam et al., 2016c). Moreover, the climatic factors are changing rapidly in Malaysia and have been exerting having adverse impacts on food production (Alam et al., 2010, 2011, 2012b). In this country, carbon dioxide $\left(\mathrm{CO}_{2}\right)$ emissions have increased by $290.7 \%$ during the period of 1990-2011 (IEA, 2013) and is included in the list of 30 largest greenhouse gas emitters. Moreover, in 2016, CO2 emissions per capita for Malaysia was 8.53 metric tons with an annual growth rate of $3.09 \%$, and Malaysia is ranked 28th in the world (BP, 2018). Alam et al., (2016b) also found significant direct and indirect impacts of climatic factors on household food security. In the case of level of food security, among the low-income rural communities, $50 \%$ or more of the households face some level of food insecurity, reporting with $34.5 \%$ of child hunger (Shariff \& Khor, 2008). Studies also show different rates for urban and rural households with food insecurity in Malaysia, such as the rate among the urban low-income households, which is, at 66.6\% (Zalilah, 1998) and 65.7\% (Zalilah \& Ang, 2001), and the rate among rural low-income households at 58\% (Shariff \& Khor, 2008).

Therefore, understanding the adaptation ability of households to food insecurity, effectiveness of the current strategies of adaptation to food insecurity, and determining the required supports for adaptation to food insecurity are essential to offer a valuable tool for planning and evaluating the achievement of Vision 2020. The understanding and the determination would help Malaysia to become a fully developed nation by the year of 2020 with a view to increasing and improving food security and removing poverty and hunger in Malaysia. Hence, this study is an attempt to conduct an in depth assessment on the available resilience factors and the adaptation practices carried out by poor and low-income households in East Coast Economic Region (ECER) to adapt to food insecurity, and the expected support for adaptation to food insecurity.

\section{Methodology}

\subsection{Study Area}


For the empirical assessment, this study mostly relied on primary data collected through an extensive questionnaire survey at the household level in the East Coast Economic Region (ECER) in Malaysia. This study selected the ECER as the study area because the ECER encompasses more than half of the Peninsular Malaysia with the area of about 66,000 sq kilometers that covers the states of Kelantan, Terengganu, Pahang, and the district of Mersing in Johor (Figure 1). ECER is crucial for two major reasons: (a) ECER is the most vulnerable area in Malaysia due to climatic changes; and (b) the income level in this region is low, and the poverty rate is high, which is a hindrance to achieving Vision 2020 (Alam et al., 2012a; ECER Master Plan. 2007, 2008). The population of ECER was about 3.95 million, which represented $14.8 \%$ of the total population of Malaysia in 2005. In 2004, the incidences of poverty were $10.6 \%, 4 \%$, and $15.4 \%$ in Kelantan, Pahang, and Terengganu, respectively, whereas for overall Malaysia, it was $5.7 \%$. At the same time, the incidences of hardcore poverty were $1.3 \%, 1.0 \%$, and $4.4 \%$ in Kelantan, Pahang, and Terengganu respectively, whereas for overall Malaysia, it was 1.2\%. Moreover, there were about 45,000 paddy farmers in the ECER, and the average productivity per worker was RM 11,915 whereas the national agriculture productivity per worker was RM 15,355 (ECER Master Plan. 2007, 2008).

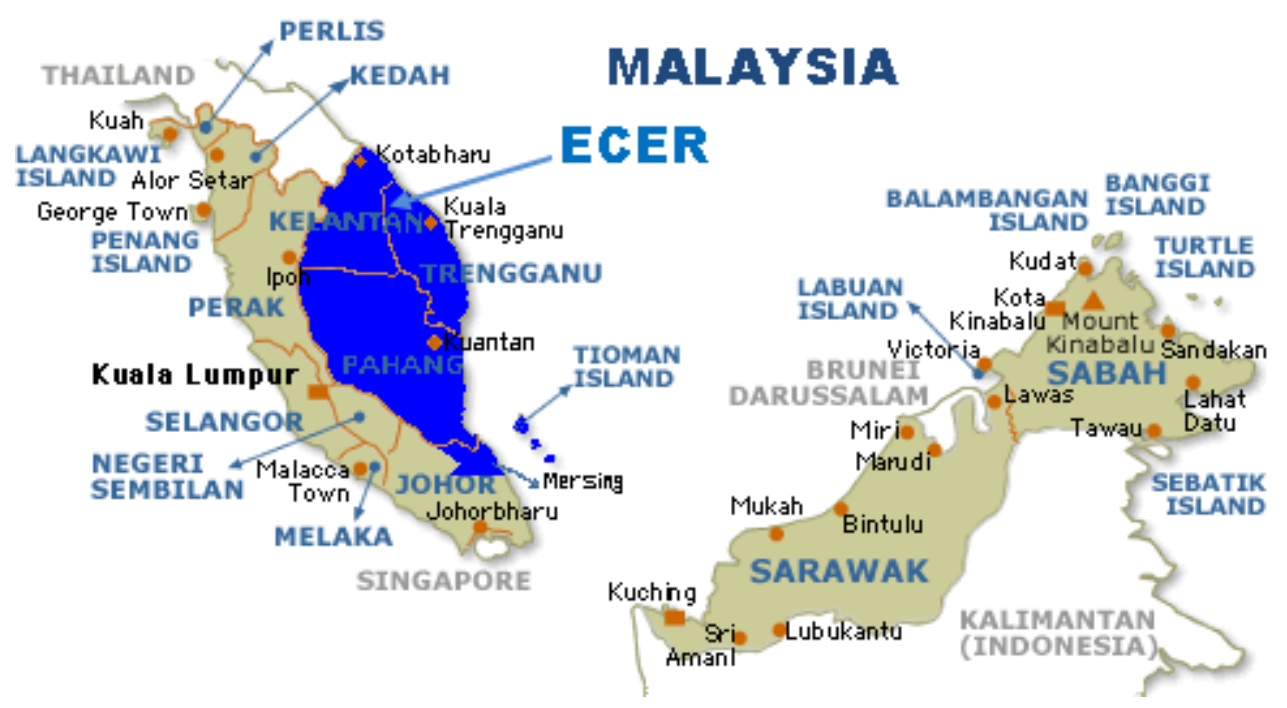

Figure 1: Location of Study Area (ECER-Malaysia)

Source: Alam et al., 2012a

ECER is mainly an agricultural region; as of 2004, all crops production covered a total area of 2.22 million ha in the ECER (34.8\% of Peninsular Malaysia). However, in 2008, the government had officially launched a large development project, East Coast Economic 
Region Development Project, to develop five key areas - manufacturing, oil, gas \& petrochemicals, tourism, agriculture, and human capital development. With the objective of fast-forwarding the inflow of Foreign Direct Investment (FDI) and industrialization in the region, ECER Special Economic Zone (ECER SEZ) and Malaysia-China Kuantan Industrial Park were initiated in this area. Therefore, the ECER was expected to implement projects worth an estimated RM 112 billion in value by the year 2020. The ECER Special Economic Zone (SEZ) was expected to generate up to RM 90 billion in investments and contribute RM 23 billion to the national Gross Domestic Product (GDP), as well as create 220,000 new jobs out of the 560,000 jobs identified (ECER Master Plan. 2007, 2008).

\subsection{Data Collection}

The study followed the two-stage cluster random sampling technique. Initially the samples were clustered by location and then by poverty category. Finally, from each category, samples were picked randomly from the E-Kasih database, which is an integrated database system that enlists poor households at the national level to plan, implement, and monitor poverty programs. The urban area of Kuantan and the rural area of Pekan were selected from the Pahang state. The urban area of Kota Bharu and the rural area of Tumpat were selected from the Kelantan state. The urban area of Kuala Terengganu and rural area of Marang were selected from the Terengganu state.

Based on the formula of required size of samples (Yamane, 1967: 886), first, 400 samples were selected according to the proportion of population distribution. However, to ensure a good number of observations for each group, which was needed for sound statistical analysis for any particular group, another 100 households were added to the sample. However, while targeting the sample size to be 500, after collecting and validating the data, finally, 460 households retained in the sample.

A structured interview based on a questionnaire was is used to collect data; the respondents provided the answers and the enumerators filled -up the questionnaires. The regular enumerators of the Implementation Coordination Unit (ICU) agency from Pahang, Kelantan, and Terengganu conducted the survey in Jul-Oct 2012.

\subsection{Identification of Variables}


There are four dimensions of food security, such as availability of food, stability of supply, accessibility to food, and utilization of food (FAO, 2005, 2008). The availability of food means sufficient quantities of quality food that is available at household level. The accessibility of food means a household's access to sufficient resources, including a set of all commodity bundles that an individual can gain access to on the basis of the legal, economic, political, and social arrangement of a community, where they live for getting quality foods for a nutritious meal. Food utilization shows the significance of non-food inputs in food security, such as proper diet, clean water, healthcare, and sanitation to gain nutritional well-being by which all physiological requirements are met. Food system stability refers to a household having access to sufficient food at all times so that they should not risk losing access to food as a result of a sudden crisis, such as an economic or climatic change crisis or cyclical occurrence, like as seasonal food insecurities.

In this study, the household status of food accessibility and household food availability were considered as the dependent variables. Household food availability was based on the measurement of the direct perception of the household, and household status of food accessibility measurement was based on the frequency of calculation. To measure the status of household food availability, households were asked about their food status in the previous month of interview (see Table 2), and to measure the status of household food accessibility, this study followed the direct measuring questionnaire-based techniques developed by Coates et al. (2007) for USAID, which is known as the Household Food Insecurity Access (HFIA) (Table 1).

Household Food Insecurity Access (HFIA) was calculated for each household by assigning a code 1-4, where 4=Food Secure Access, 3=Mildly Food Insecure Access, 2=Moderately Food Insecure Access, and 1=Severely Food Insecure Access. Initially, the data were coded as frequency-of-occurrence as 0 for all cases where the answer to the corresponding occurrence question was "no" (i.e., if $\mathrm{Q} 1=0$ then $\mathrm{Q} 1 \mathrm{a}=0$, etc.). Then, the intensities of the occurrence of nine questions were measured in three frequencies - rarely (12 times per month) or sometimes (3-10 times) or often (10+ times per month) -indicated by Q1a to Q9a (Table 1). Finally, the four food accessibility categories were created sequentially, to ensure that households were classified according to their most severe response. 
- Category $=4$ if $[(\mathrm{Q} 1=0$ or $\mathrm{Q} 1=1)$ and $\mathrm{Q} 2=0$ and $\mathrm{Q} 3=0$ and $\mathrm{Q} 4=0$

and $\mathrm{Q} 5=0$ and $\mathrm{Q} 6=0$ and $\mathrm{Q} 7=0$ and $\mathrm{Q} 8=0$ and $\mathrm{Q} 9=0]$

- Category $=3$ if $[(\mathrm{Q} 1 \mathrm{a}=2$ or $\mathrm{Q} 1 \mathrm{a}=3$ or $\mathrm{Q} 2 \mathrm{a}=1$ or $\mathrm{Q} 2 \mathrm{a}=2$ or $\mathrm{Q} 2 \mathrm{a}=3$ or

$\mathrm{Q} 3 \mathrm{a}=1$ or $\mathrm{Q} 4 \mathrm{a}=1)$ and $\mathrm{Q} 5=0$ and $\mathrm{Q} 6=0$ and $\mathrm{Q} 7=0$ and

$\mathrm{Q} 8=0$ and $\mathrm{Q} 9=0]$

- Category $=2$ if $[(\mathrm{Q} 3 \mathrm{a}=2$ or $\mathrm{Q} 3 \mathrm{a}=3$ or $\mathrm{Q} 4 \mathrm{a}=2$ or $\mathrm{Q} 4 \mathrm{a}=3$ or $\mathrm{Q} 5 \mathrm{a}=1$ or

$\mathrm{Q} 5 \mathrm{a}=2$ or $\mathrm{Q} 6 \mathrm{a}=1$ or $\mathrm{Q} 6 \mathrm{a}=2$ ) and $\mathrm{Q} 7=0$ and $\mathrm{Q} 8=0$

and Q9=0]

- Category $=1$ if $[\mathrm{Q} 5 \mathrm{a}=3$ or $\mathrm{Q} 6 \mathrm{a}=3$ or $\mathrm{Q} 7 \mathrm{a}=1$ or $\mathrm{Q} 7 \mathrm{a}=2$ or $\mathrm{Q} 7 \mathrm{a}=3$ or

$\mathrm{Q} 8 \mathrm{a}=1$ or $\mathrm{Q} 8 \mathrm{a}=2$ or $\mathrm{Q} 8 \mathrm{a}=3$ or $\mathrm{Q} 9 \mathrm{a}=1$ or $\mathrm{Q} 9 \mathrm{a}=2$ or $\mathrm{Q} 9 \mathrm{a}=3$ ]

The following table illustrates the above four categorizations, where every household was placed in a single, unique category based on the set of responses (Table 1).

Table 1: Measurement of Household Food Insecurity Access Scale

\begin{tabular}{|c|c|c|c|c|}
\hline & \multirow[b]{2}{*}{ HFIAS Measurement Issues } & \multicolumn{3}{|c|}{ Category of food insecurity (access) } \\
\hline & & $\begin{array}{c}\text { Rarely (1-2 times } \\
\text { per month) }\end{array}$ & $\begin{array}{l}\text { Sometimes } \\
\text { (3-10 times) }\end{array}$ & $\begin{array}{c}\text { Often }(10+\text { times } \\
\text { per month })\end{array}$ \\
\hline$\overline{\mathrm{Q} \text { Q1 }}$ & Worry about food & & & \\
\hline Q2 & Unable to eat preferred food & & & \\
\hline Q3 & Eat just a few kinds of foods & & & \\
\hline Q4 & Eat foods they really do not want to eat & & & \\
\hline Q5 & Eat a smaller meal & & & \\
\hline Q6 & Eat fewer meals in a day & & & \\
\hline Q7 & No food of any kind in the household & & & \\
\hline Q8 & Go to sleep hungry & & & \\
\hline Q9 & Spend whole day and night without eating & & & \\
\hline & 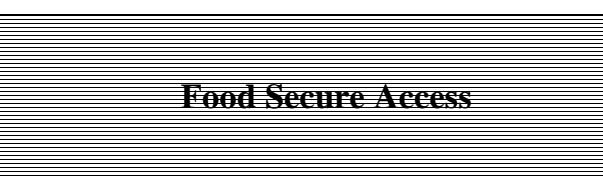 & $\begin{array}{l}\text { Mildily Food } \\
\text { Insecure }\end{array}$ & $\begin{array}{c}\text { Moderately } \\
\text { Food } \\
\text { Insecure }\end{array}$ & $\begin{array}{l}\text { Senemely food } \\
\text { Insecure }\end{array}$ \\
\hline
\end{tabular}

Source: Coates et al. 2007; Alam et al. 2016a 
In the present study, resilience refers to the household's ability or strength to cope with stress and hardship in case of actual or expected food insecurity. Household resilience factors are categorized as socioeconomic, physical assets, and livelihood strategy and behavior. Adaptation practices refer to actions or adjustments in ecological, social, or economic systems in response to actual or expected food insecurity. Factors of adaptation practices and expected support are categorized as climatic and non-climatic factors.

There are very few studies available to get a standardized list of resilience and adaptation variables relevant to household food security. However, literature shows different types of factors related to food security, such as political, economic and natural indicators, infrastructure, security (Lovendal \& Knowles, 2006; Nyariki \& Wiggins, 1997); hygiene, sanitation, unsafe water supply (Makinen et al., 2000); isolation from markets (Webb et al., 1992; Negatu, 2006); demography (Baer \& Madrigal, 1993; Lino, 1996; Iram \& Butt, 2004; Piaseu, 2006); health and nutrition (Myntti, 1993; Pfeiffer et al., 2001; Hindin, 2006;Fartahun et al., 2007); food budget, savings (Cristofar \& Basiotis, 1992; Rose et al., 1995; Olson et al., 1997); locality (Maxwell et al., 1999); technology (Nyariki \& Wiggins, 1997; Negatu, 2006); access to land, land tenure system, land productively (ECA, 2004); transportation and unemployment (Negatu, 2006); etc. Interestingly, studies also show that many low-income households have food security and many households above the poverty line present indications of food insecurity (Olson et al., 1997; Rose, 1999). Thus, this study used a list of variables that were collected based on the literature related to the four dimensions of food security and conducted an initial pilot survey. The list of the independent variables of the study consisted of different resilience factors of a household (X1-X18), adaptation practices of a household (X19-X46), and the expected external support for adaptation to food security (X47-X58). The measurements of all of the variables are given in appendix 1.

\subsection{Model Specification}

To check the relationship between household status for food security and their resilience factors, the following ordinal regressions was done based on the logit model:

$$
\begin{aligned}
& \mathrm{Z}_{\mathrm{i}}=f\left(\mathrm{X}_{\mathrm{i}}\right) \\
& \mathrm{Z}_{\mathrm{i}}=(\mathrm{Y} 1, \mathrm{Y} 2) \\
& \mathrm{X}_{\mathrm{i}}=(\mathrm{X} 1 \ldots \mathrm{X} 18)
\end{aligned}
$$


To check the relationship between household status of food security and their adaptation practices to food insecurity, the following ordinal regressions were carried out based on the logit model:

$$
\begin{aligned}
& \mathrm{Z}_{\mathrm{i}}=f\left(\mathrm{X}_{\mathrm{i}}\right) \\
& \mathrm{Z}_{\mathrm{i}}=(\mathrm{Y} 1, \mathrm{Y} 2) \\
& \mathrm{X}_{\mathrm{i}}=(\mathrm{X} 19 \ldots \mathrm{X} 46)
\end{aligned}
$$

Further, to find out the relationship between household status of food security and types of expected support to adapt to food insecurity, the following ordinal regressions were conducted based on the logit model:

$$
\begin{aligned}
& \mathrm{Z}_{\mathrm{i}}=f\left(\mathrm{X}_{\mathrm{i}}\right) \\
& \mathrm{Z}_{\mathrm{i}}=(\mathrm{Y} 1, \mathrm{Y} 2) \\
& \mathrm{X}_{\mathrm{i}}=(\mathrm{X} 47 \ldots \mathrm{X} 58)
\end{aligned}
$$

Finally, a correlation analysis was conducted in order to find out the relationship among the relevant variables and to check the multicollinearity problem.

\section{Results and Analysis}

\subsection{Status of Household Food Security}

In terms of household food availability, $14.8 \%$ respondents said that they had enough food according to their likings but the majority $(41.1 \%)$ of the households mentioned that they always did have enough of the food they liked. $9.1 \%$ of the households mentioned that they frequently stayed hungry (Table 2).

Table 2: Family Food Status in the Previous Month of Interview

\begin{tabular}{lcc}
\hline Food Status in the Family & No of Households & \% of Total \\
\hline \hline Enough of the kinds of food you want to eat & 68 & $14.8 \%$ \\
Enough but not always the kinds of food you want & 189 & $41.1 \%$ \\
Sometimes not enough to eat & 100 & $21.7 \%$ \\
Often not enough to eat & 61 & $13.3 \%$ \\
Frequently stay hungry & 42 & $9.1 \%$
\end{tabular}




\begin{tabular}{lll}
\hline Total & 460 & $100 \%$
\end{tabular}

Based on the HFIA category, this study found that $52.8 \%$ of the households were under the category of "food secure" (Table 3). Among the surveyed households, $23.3 \%$ faced mild food insecurity (access); out of them, many of them were worried about not having enough food sometimes or often, and/or unable to eat preferred foods, and/or rarely ate a more monotonous diet than desired and/or also rarely ate some undesirable foods.

Table 3: Distribution of Household Food Insecurity Access (HFIA)

\begin{tabular}{lcc}
\hline \multicolumn{1}{c}{ HFIA Category } & HFIA Prevalence & \% of HFIA Prevalence \\
\hline \hline 4= Food secure Access & 243 & $52.8 \%$ \\
3= Mildly Food Insecure Access & 107 & $23.3 \%$ \\
2= Moderately Food Insecure Access & 66 & $14.3 \%$ \\
1= Severely Food Insecure Access & 44 & $9.6 \%$ \\
\hline Total & 460 & $100.0 \%$ \\
\hline
\end{tabular}

Among the households, the result showed that $14.3 \%$ felt moderately food insecurity. These households frequently sacrificed quality of food by eating a monotonous diet or undesirable food sometimes or often, and/or reduced eating the quantity of food rarely or sometimes. There were $9.6 \%$ of households that felt severely food insecurity ; in addition, they graduated to cutting back on meal size or number of meals often, and/or experienced any of the three most severe conditions. These conditions included running out of food, going to bed hungry, or going a whole day and night without eating - even as infrequently as rarely or at least once in the previous month.

\subsection{Household Status of Food Security and Resilience Factors}

The regression models based on Equation 1 show that some of the resilience factors have a statistically significant relationship with household food availability and food accessibility (Table 4). The p-values of the likelihood ratio (LR) statistics for both models shown below are 0.0000001 , which suggests a good fit of the models. The pseudo R-squares are 0.12 for food availability and 0.15 for the food accessibility models. 
Among the socioeconomic resilience factors, improvement of household economic conditions, increase of the ratio of earning family members to the total family members, and availability of savings have been found to be statistically significant, and this indicates more food availability and accessibility at the household level. On the other hand, the higher the number of school-going children the lower the food security in the household with both statistical and significant indication.. For a one unit increase in the number of school going children, the odds of food availability and accessibility at the household are decreased by $25.4 \%(1-0.746)$ and $26.7 \%(1-0.733)$, respectively.

Table 4: The Relationship between Household Food Security and Resilience Factors

\begin{tabular}{|c|c|c|c|c|}
\hline Variable & Odds Ratio & P-value & Odds Ratio & P-value \\
\hline \multicolumn{5}{|c|}{ Household resilience factors: socioeconomic } \\
\hline $\mathrm{X} 1$ & 1.058 & 0.643 & 0.992 & 0.954 \\
\hline $\mathrm{X} 2$ & $0.746^{*}$ & 0.000 & $0.733^{*}$ & 0.000 \\
\hline $\mathrm{X} 3$ & $1.504^{*}$ & 0.000 & $1.344 *$ & 0.001 \\
\hline $\mathrm{X} 4$ & 1.280 & 0.376 & 1.589 & 0.161 \\
\hline $\mathrm{X} 5$ & 0.747 & 0.328 & 0.689 & 0.235 \\
\hline $\mathrm{X} 6$ & $1.403^{*}$ & 0.002 & $1.704^{*}$ & 0.000 \\
\hline $\mathrm{X} 7$ & $2.687 *$ & 0.000 & $2.922 *$ & 0.000 \\
\hline \multicolumn{5}{|c|}{ Household resilience factors: physical assets } \\
\hline $\mathrm{X} 8$ & 0.979 & 0.912 & 1.162 & 0.478 \\
\hline X9 & 1.122 & 0.632 & 1.361 & 0.230 \\
\hline $\mathrm{X} 10$ & 0.956 & 0.714 & 1.012 & 0.931 \\
\hline $\mathrm{X} 11$ & $1.607^{\wedge}$ & 0.029 & $1.989 *$ & 0.003 \\
\hline \multicolumn{5}{|c|}{ Household resilience factors: livelihood strategy and behavior } \\
\hline $\mathrm{X} 12$ & 1.253 & 0.272 & 1.081 & 0.730 \\
\hline $\mathrm{X} 13$ & 1.100 & 0.409 & 1.120 & 0.370 \\
\hline X14 & 1.022 & 0.859 & 1.022 & 0.867 \\
\hline $\mathrm{X} 15$ & $1.485 \sim$ & 0.010 & $1.531^{*}$ & 0.009 \\
\hline $\mathrm{X} 16$ & 1.161 & 0.223 & $1.257 \sim$ & 0.092 \\
\hline $\mathrm{X} 17$ & 0.917 & 0.542 & 0.846 & 0.282 \\
\hline $\mathrm{X} 18$ & 1.036 & 0.595 & 0.984 & 0.821 \\
\hline Dependent Variable & \multicolumn{2}{|c|}{$\mathrm{Y} 1$} & \multicolumn{2}{|c|}{$\mathrm{Y} 2$} \\
\hline Pseudo R-squared & \multicolumn{2}{|c|}{0.123} & \multicolumn{2}{|c|}{0.15} \\
\hline $\begin{array}{l}\text { P-value (LR } \\
\text { statistic) }\end{array}$ & \multicolumn{2}{|c|}{$<0.0000001$} & \multicolumn{2}{|c|}{$<0.0000001$} \\
\hline
\end{tabular}

$*, \wedge, \sim$ indicates significant at $1 \%, 5 \%, 10 \%$ significance level, respectively 
As a physical asset of household, availability of transport for buying food was has been found to be statistically significant, and this indicates more about food availability and accessibility at the household level. The odds of household food availability and accessibility were $61 \%$ and $99 \%$ higher for those who have transportation. Furthermore, among the livelihood strategy and behavior under resilience factors, households managing waste properly was also statistically significant, indicating more food availability and accessibility in the household. Households that had knowledge about maintaining the nutrition level and had a good sense of hygiene were found to be statistically significant to cause food accessibility at the household level.

\subsection{Household Status of Food Security and Adaptation Practices}

The regression models based on Equation 2 suggest that some of the adaptation approach from both climatic and non-climatic factors had a statistical and significant relationship with household food availability and accessibility (Table 5). The p-values of the likelihood ratio (LR) statistics for both models were below 0.0000001, which shows a very good fit of the models. The pseudo R-squares were 0.18 for food availability and 0.22 for the food accessibility models.

Among the non-climatic approach of adaptation, it was found that reducing food variation explained statistically and significantly both food availability and accessibility at the household level. However, reducing fruit and vegetable consumption as well as taking cheap medical treatment for adaptation did not statistically and significantly indicate food availability and accessibility at the household level. Moreover, households that applied the technique of changing the food processing system held $66 \%$ more odds in food availability in the household. Moreover, , the adaptation techniques of cooking whatever food available and delaying medical treatments as well as migrating to other places statistically and significantly indicated household food accessibility, but engaging supplementary job as an adaptation approach statistically and significantly did not indicate to have food accessibility at the household level.

Table 5: The Relationship between Household Food Security and Adaptation Practices 


\begin{tabular}{|c|c|c|c|c|}
\hline Variable & $\begin{array}{l}\text { Odds } \\
\text { Ratio }\end{array}$ & P-value & $\begin{array}{l}\text { Odds } \\
\text { Ratio }\end{array}$ & P-value \\
\hline \multicolumn{5}{|c|}{ Adaptation Approaches: Non-climatic factors } \\
\hline X19 & 1.214 & 0.122 & 1.158 & 0.270 \\
\hline $\mathrm{X} 20$ & $1.662 \sim$ & 0.086 & 1.504 & 0.191 \\
\hline $\mathrm{X} 21$ & 1.106 & 0.763 & 0.860 & 0.675 \\
\hline $\mathrm{X} 22$ & 0.943 & 0.835 & 0.804 & 0.443 \\
\hline $\mathrm{X} 23$ & 0.676 & 0.157 & 0.669 & 0.169 \\
\hline $\mathrm{X} 24$ & 1.084 & 0.767 & $1.663 \sim$ & 0.074 \\
\hline $\mathrm{X} 25$ & 0.724 & 0.259 & 0.711 & 0.266 \\
\hline $\mathrm{X} 26$ & $1.635 \sim$ & 0.079 & $1.663 \sim$ & 0.092 \\
\hline $\mathrm{X} 27$ & $0.548^{\wedge}$ & 0.040 & $0.521^{\wedge}$ & 0.033 \\
\hline $\mathrm{X} 28$ & 0.909 & 0.748 & 1.020 & 0.948 \\
\hline X29 & $0.505^{\wedge}$ & 0.016 & $0.554^{\wedge}$ & 0.047 \\
\hline $\mathrm{X} 30$ & 1.723 & 0.067 & $1.762 \sim$ & 0.065 \\
\hline $\mathrm{X} 31$ & 0.665 & 0.163 & $0.537^{\wedge}$ & 0.043 \\
\hline $\mathrm{X} 32$ & 1.598 & 0.125 & $2.188^{\wedge}$ & 0.015 \\
\hline \multicolumn{5}{|c|}{ Adaptation Approaches: Climatic factors } \\
\hline $\mathrm{X} 33$ & $0.841^{\wedge}$ & 0.173 & 0.930 & 0.590 \\
\hline $\mathrm{X} 34$ & $2.352^{*}$ & 0.005 & $1.670 \sim$ & 0.098 \\
\hline $\mathrm{X} 35$ & 1.345 & 0.314 & 0.844 & 0.584 \\
\hline $\mathrm{X} 36$ & 0.765 & 0.375 & 0.688 & 0.212 \\
\hline $\mathrm{X} 37$ & $0.539^{\wedge}$ & 0.021 & $0.535^{\wedge}$ & 0.023 \\
\hline X38 & 1.122 & 0.708 & 1.592 & 0.142 \\
\hline X39 & 0.960 & 0.870 & 1.059 & 0.829 \\
\hline $\mathrm{X} 40$ & $0.545^{\wedge}$ & 0.019 & $0.494 *$ & 0.009 \\
\hline $\mathrm{X} 41$ & 0.831 & 0.503 & 0.947 & 0.851 \\
\hline $\mathrm{X} 42$ & $0.560 \sim$ & 0.100 & 0.639 & 0.206 \\
\hline $\mathrm{X} 43$ & 1.006 & 0.987 & 1.154 & 0.706 \\
\hline $\mathrm{X} 44$ & 0.732 & 0.286 & 0.872 & 0.657 \\
\hline $\mathrm{X} 45$ & 1.216 & 0.517 & 1.013 & 0.967 \\
\hline $\mathrm{X} 46$ & 1.693 & 0.110 & 1.452 & 0.264 \\
\hline Dependent Variable & \multicolumn{2}{|c|}{$\mathrm{Y} 1$} & \multicolumn{2}{|c|}{ Y2 } \\
\hline Pseudo R-squared & \multicolumn{2}{|c|}{0.06} & \multicolumn{2}{|c|}{0.07} \\
\hline P-value (LR statistic) & \multicolumn{2}{|c|}{$<0.0000001$} & \multicolumn{2}{|c|}{$<0.0000001$} \\
\hline
\end{tabular}

$*, \wedge, \sim$ indicates significant at 1\%,5\%,10\% significance level, respectively

Among the climatic approach of adaptation, applying the technique of changing food processing system was found to be statistically significant to explain both food availability 
and accessibility at the household level. However, reducing the number of meals and food variation did not statistically and significantly indicate food availability and accessibility at the household level. In addition, households reducing spending on children's education for adaptation to climatic food insecurity did not statistically and significantly indicate gaining food availability.

\subsection{Household Status for Food Security and Expected Supports}

There are a few external agencies, such as the district office, department of social welfare, health clinic, farmer's association, NGO, political parties, zakah board, and social support program, etc. that provide a few services. Among these services, a few households mentioned about receiving RM 500 from the Malaysia fund and Rancangan Makanan Tambahan (RMT) or Food Supplement Program, RM 200 from the fish development board, RM 300 as well as kitchen staff ( e.g. stove, cooking pot, etc.) valued at RM150 from the department of social welfare, RM 4800 for children's aid from the Department of Social Welfare (JKM), RM 200 every month from the farmer's association, and a few funds from charity or zakah. Among the households, $67.8 \%$ mentioned that the external services were are satisfactory and $63.9 \%$ followed the recommendation and guidelines provided by these agencies. However, households mentioned that the support was not adequate, and they expected more support.

Among the expected support, $65 \%$ of the households mentioned the necessity for overall external support to adapt to food insecurity (Table 6). Among the climatic relevant supports, $63.5 \%$ expected support for climatic related subsidies or rationing for food. It is also found that $94.3 \%$ expected support from food aids for emergency time; 93\% expected support for providing emergency services for a time of disaster, and $90.9 \%$ expected support for special food distribution arrangements in emergency times. Among the relevant general support, $81.7 \%$ expected support for income increasing program or incentive; $84.1 \%$ expected support for road and transport infrastructure improvement; 85.9\% expected support for improving drinking water services; $87.6 \%$ expected support for improving health and medical services; $79.3 \%$ expected support for updating the food distribution channel; $90.4 \%$ expected support for monitoring and adjustment in price at the local market, and $68.7 \%$ expected support for improving agriculture and other agency services.

Table 6: Expected Support to Adapt to Food Insecurity 


\begin{tabular}{|c|c|c|c|c|c|c|c|c|c|}
\hline \multirow{2}{*}{$\begin{array}{l}\text { New Supports } \\
\text { for adaptation }\end{array}$} & \multicolumn{5}{|c|}{ Observation Scale* } & \multirow{2}{*}{$\begin{array}{l}\text { Average } \\
\text { value of } \\
\text { the score }\end{array}$} & \multirow{2}{*}{ S.D. } & \multirow{2}{*}{$\begin{array}{c}\text { Proportion of } \\
\text { Needed(4 \& 5) } \\
\text { Observation } \\
\end{array}$} & \multirow{2}{*}{$\begin{array}{l}\text { Proportion of } \\
\text { Not Needed(1 \& } \\
\text { 2) Observation }\end{array}$} \\
\hline & 1 & 2 & 3 & 4 & 5 & & & & \\
\hline \multicolumn{10}{|c|}{ Climatic and non-climatic common factors } \\
\hline $\mathrm{X} 47$ & 37 & 5 & 119 & 220 & 79 & 3.65 & 1.04 & $65.0 \%$ & $9.1 \%$ \\
\hline \multicolumn{10}{|c|}{ Non-climatic factors } \\
\hline $\mathrm{X} 48$ & 17 & 1 & 66 & 234 & 142 & 4.05 & 0.89 & $81.7 \%$ & $3.9 \%$ \\
\hline $\mathrm{X} 49$ & 21 & 17 & 35 & 244 & 143 & 4.02 & 0.97 & $84.1 \%$ & $8.3 \%$ \\
\hline $\mathrm{X} 50$ & 15 & 16 & 34 & 187 & 208 & 4.21 & 0.96 & $85.9 \%$ & $6.7 \%$ \\
\hline X51 & 16 & 8 & 33 & 159 & 244 & 4.32 & 0.94 & $87.6 \%$ & $5.2 \%$ \\
\hline X52 & 15 & 6 & 74 & 219 & 146 & 4.03 & 0.91 & $79.3 \%$ & $4.6 \%$ \\
\hline $\mathrm{X} 53$ & 15 & 3 & 26 & 243 & 173 & 4.21 & 0.84 & $90.4 \%$ & $3.9 \%$ \\
\hline X54 & 77 & 12 & 55 & 195 & 121 & 3.59 & 1.35 & $68.7 \%$ & $19.3 \%$ \\
\hline \multicolumn{10}{|l|}{ Climatic factors } \\
\hline X55 & 43 & 75 & 50 & 175 & 117 & 3.54 & 1.28 & $63.5 \%$ & $25.7 \%$ \\
\hline X56 & 15 & 2 & 9 & 207 & 227 & 4.37 & 0.83 & $94.3 \%$ & $3.7 \%$ \\
\hline $\mathrm{X} 57$ & 13 & 1 & 18 & 172 & 256 & 4.43 & 0.82 & $93.0 \%$ & $3.0 \%$ \\
\hline $\mathrm{X} 58$ & 13 & 5 & 24 & 229 & 189 & 4.25 & 0.84 & $90.9 \%$ & $3.9 \%$ \\
\hline
\end{tabular}

The regression models based on Equation 3 shows some of the expected support related to both climatic and non-climatic factors that have a statistically significant relationship with household food availability and accessibility (Table 7). The p-values of the likelihood ratio (LR) statistics for both models are below 0.0000001 , which suggests a very good fit of the models. The pseudo R-squares are 0.02 for food availability and 0.022 for the food accessibility models.

Table 7: The Relationship between Household Status of Food Security and Types of Expected Support

\begin{tabular}{ccccc}
\hline Variable & Odds Ratio & P-value & Odds Ratio & P-value \\
\hline Expected Supports: Related to both Climatic & \& & Non-climatic & factors & \\
X47 & $0.749^{\wedge}$ & 0.017 & $0.762^{\wedge}$ & 0.034 \\
Expected Supports: Related to Non-climatic & factors & & \\
X48 & 0.826 & 0.215 & 0.933 & 0.669 \\
X49 & 1.023 & 0.871 & 0.935 & 0.666 \\
X50 & 0.958 & 0.781 & 0.984 & 0.919 \\
X51 & $1.389 \sim$ & 0.058 & $1.460^{\wedge}$ & 0.036 \\
X52 & 0.968 & 0.854 & 0.915 & 0.636 \\
X53 & 1.243 & 0.251 & 1.355 & 0.133 \\
X54 & 1.011 & 0.911 & 0.932 & 0.471 \\
Xxpected Supports: Related to Climatic factors & & & \\
X55 & 0.914 & 0.334 & 0.985 & 0.877 \\
X56 & 0.963 & 0.827 & 0.887 & 0.495
\end{tabular}




\begin{tabular}{|c|c|c|c|c|}
\hline $\mathrm{X} 57$ & 0.747 & 0.136 & $0.686 \sim$ & 0.071 \\
\hline $\mathrm{X} 58$ & $1.559^{\wedge}$ & 0.033 & $1.706^{\wedge}$ & 0.015 \\
\hline Dependent Variable & \multicolumn{2}{|c|}{ Y1 } & \multicolumn{2}{|c|}{$\mathrm{Y} 2$} \\
\hline Pseudo R-squared & \multicolumn{2}{|c|}{0.020} & \multicolumn{2}{|c|}{0.022} \\
\hline P-value (LR statistic) & \multicolumn{2}{|c|}{0.006} & \multicolumn{2}{|c|}{0.022} \\
\hline
\end{tabular}

$\wedge$ and $\sim$ indicates significant at $5 \%$ and $10 \%$ significance level, respectively

Among different types of expected support, the statistically significant support related to both climatic and non-climatic factors was the overall support to ensure food security. Non-climatic factors improved the health and medical services whereas the climatic factors provided emergency services for disaster time and special food distribution arrangements in times of emergency.

The statistically significant odds ratio values indicate that the support to improve health and medical services and the support for special food distribution arrangements in emergency times were the expectations of the food available and accessible households. Holding other things constant, for a unit increase in the expectation of support for improving health and medical services, the odds in favor of food availability and accessibility in the household increased by 38.9 and $46 \%$, respectively. Similarly, there was a $55.9 \%$ and $70.6 \%$ increase of odds to food availability and accessibility in the household for a one-unit increase in the expectation of support for special food distribution arrangements in emergency times.

However, the overall support to ensure household food security is the common expectation of the food unavailable and inaccessible households. There was a $25 \%$ and $24 \%$ decrease of odds to food availability and accessibility in households for a one-unit increase in the expectation of overall support to ensure household food security. Moreover, households that did not have access to food also expected to get support by providing emergency services for disaster times. This means that holding other things constant, for a unit increase in the expectation of support for providing emergency services for disaster times, the odds in favor of household food accessibility decreased by $31.4 \%$.

\subsection{Model Efficiency Test}

When two variables are considered highly correlated to each other and explain the dependent variable, it may cause a multicollinearity problem. multicollinearity problem occurs when the correlation values are considered 0.8 or above (Field, 2000: 2, 44-322). To identify if there are any multicollinearity problems present among the variables, the Pearson Correlation tests 
were performed in the study. The result shows that the correlation values among the variables for resilience factors (Appendix 2), adaptation approaches (Appendix 3), and expected support (Appendix 4) fell below 0.8, which indicates that multicollinearity was absent among the variables.

\section{Discussion}

This study found several resilience factors, adaptation approaches, and expected external support to be statistically significant to explain household status of food security. However, these variables also differed between food secure and insecure groups. Results show that at the household level, the food insecure households needed to be more focused on the adaptation techniques that were significantly applied by the food secured group. Moreover, the findings of this study are supported by other studies around the world. For instance, a study from Smith and Frankenberger (2018) during the flood in 2014 found some suggestive evidence that resilience (e.g., social capital, human capital, exposure to information, asset holdings, livelihood diversity, safety nets, access to markets and services, women's empowerment, governance, and psycho-social capabilities) reduced the negative impact of the flooding on household food security for Bangladesh.

At the local scale, research on food systems resilience has mostly focused on disaster response case studies and detailed evaluations of infrastructure, governance, and social networks (Béné et al 2016). At the global level, resilience research has a different focus, evaluating economic patterns and relationships rather than food security for individuals or households by tracking how shocks to the food system propagate internationally (Marchand et al 2016). However, this study also found several support needed to be ensured, such as increased income, encouragement to generate and develop savings related programs, arrangement of transportation and infrastructure facilities, provision of better health and medical services, special food distribution arrangements, and availability of emergency services for disaster times. They are related to both the climatic and non-climatic factors.

As ensuring food security requires food production and distribution systems function throughout disruptions (Seekell et al., 2017), to reduce food insecurity among the poor and low income households in Malaysia, involvements of relevant stakeholders are very important (Smit \& Skinner, 2002). Therefore, national governments should play a major role 
in addressing the challenging food security issues via budgets, policies, and by having legislative guidelines with efforts focused on adaptation by other interested parties. Private sector can also engage in the adaptation process in various ways, including and creating their opportunities for business. They can ensure availability of food during times of shortfall in production, and availability of inputs from agriculture as well as provision of credit against labor, harvests, etc. Banks and insurance organizations can offer different savings, credit facilities, and insurance schemes to seasonal food insecure groups. Community-based organizations (CBOs) in risk management can also contribute when there is no formal set up yet. Relying on the social capital, CBOs can help the poor and low-income Malaysian households in controlling and coping with risks as well as preventing risks, such as being the co-sponsor of local plans for infrastructure development.

Moreover, climate change affect the groups that have always been at risk of food insecurity, and it also affects new groups who become vulnerable to regional weather changing conditions (IPCC, 2007). Additionally, farmers have to deal with changing weather patterns and rising frequency and intensity of extreme weather events, resulting in making farming even more risky (IPCC, 2012). Malaysia is also adversely affected by climatic issues (Alam et al., 2010, 2011). Furthermore, changes in climate factors are likely to affect adversely the agriculture production and consequently food security of the country (Alam et al., 2017). For example, rice production in Malaysia is extremely vulnerable to weather changes and extreme conditions, such as drought and flooding. The results of a study by Vaghefi, et al. (2016) showed that during the main and off growing seasons, increase in temperature and changes rainfall pattern could be expected to reduce the rice yield by 12 and $31.3 \%$, respectively, until the year 2030. A study from Bangladesh by Farzana et al., in 2017 showed that households suffering from moderate and severe food insecurity, were more likely to adopt both financial and food compromisation coping strategies. Moreover, another study from Douxchamps et al. (2016) found that adaptation strategies improved the food security status of most households in four West African countries (Burkina Faso, Ghana and Senegal).

Therefore, the design of food security programs in Malaysia must be integrated with climate change in adaptation programs. The local, national, and regional administrations and resources need to be ensured for capacity building in communities that are particularly at risk for food insecurity as well as climate change. Furthermore, Sustainable Development Goals 
(SDGs) might be integrated with them too. Moreover, Malaysia is stepping up its efforts to improve self-sufficiency levels (SSL) in food production and preparing for the impacts of climate-related disasters to ensure food security. To achieve SDG goal 2, sustainable agriculture development is guided by the National Agrofood Policy 2011-2020 and National Commodity Policy 2011-2020 of Malaysia, which includes the use of quality seeds, breeds and fries, wider adoption of effective technologies among farmers, and establishment of new large scale food production areas (EPU, 2017). Malaysia also has been proactive in maintaining genetic diversity and undertaking research in climate-resistant crops and farmed animals.

Through the improvement of SSL of Malaysia on various agricultural product, Malaysia is still relying on imports from foreign countries in various food commodities, such as rice, fruits, dairy milk and beef. Moreover, with growing population growth, demand for food that is expected to increase by 70 to $100 \%$ by 2050 will pose a threat to food security to Malaysia. In 2015, food import bills alone hit almost RM45.4 billion while exports of only RM 27 billion left the deficit of more than RM18 billion. If this situation persists, Malaysia will likely to face the food crisis in the future (UPM, 2017). Recent studies have shown that low-income rural people are more susceptible to food crises due to the larger family size, the number of school children and unemployed mothers (Paul, 2013; Selamat et al., 2015), and the findings of Paul (2013) and Selamat et al. (2015) support this study.

To adequately deal with the effects of climate changes on food security, plans have to be initiated with a good analysis of the groups that are already particularly marginal at present. In vulnerable places where people are affected by both food insecurity and climate changes effects, increasingly adopting an integrated method that takes into account risk reduction, the resilient livelihoods, and the underlying causes of food insecurity and vulnerability is the best option (Alam et al. 2012b). Adaptation methods that influence various groups in various ways also need to be checked carefully (Stern, 2007; Pielke et al., 2007). Several adaptation methods lower some groups' vulnerability, but may increase the vulnerability in other groups instead. For an example, the devaluation of currency improves the domestic prices of food and trading goods, benefits the farmers to produce surpluses of tradable products, but that affects producers of non-tradable products negatively, such as unskilled landless laborers or subsistence farmers (FAO, 1997). 
As this study found that expected supports from other institutions were very crucial in terms of reducing food insecurity, and this aspect is absent in the study areas. There are many supporting literature on this. For example, an estimated 85.7 percent of American households were food secure throughout the entire year in 2013; out of which $62 \%$ of all food-insecure households participated in one or more of the three largest Federal food and nutrition assistance programs. Moreover, many studies have found significant relation between food security and support from different institutions (Béné et al., 2016; Fabinyi et al., 2017; Rezai et al., 2016; Thi et al., 2015; Qureshi et al., 2015).

\section{Conclusions}

Households need to apply the technique of changing food processing and storage system, gaining knowledge about maintaining nutrition level and good sense of hygiene, find alternative scope for migration, ensure savings, reducing food variation, and enough income opportunity for adaptation to food insecurity. Some prominent storage systems are canning, freezing, freeze-drying, vacuum packing, storage in gases, drying etc. (Hammond et al. 2015).

Furthermore, Malaysia should reduce its import dependency on food. Moreover, Malaysia should boost up its SSL to ensure food security for future population. Additionally, expected support from other institution, like NGOs, government agencies should increase towards poor community of Malaysia. At the same time, in the long run, climate change mitigation methods should be designed to curb nutritional challenges and food security issues due to changes in the climate. People who are vulnerable should be empowered and encouraged to adapt to climate changes by developing resilience via investments in health, social protection, education, etc.

Finally, the researchers suggest that new additional studies need to be undertaken to validate or reject the overall findings of the current study. This study found the important adaptation techniques and supports for the food insecure group. The findings of the study are empirically very new. Furthermore, the result might change over the time and based on situation. Therefore, there are huge scopes to further explore the issues discussed in this article. The results of this study can be investigated further and validated against other 
socioeconomic and demographic factors, different locations, different economic groups, and the level of food security and also by measuring in different ways.

\section{References}

Alam, M.M., Morshed, G., Siwar, C., Murad, M.W. 2012a. Initiatives and Challenges of Agricultural Crop Sector in ECER Development Projects in Malaysia. AmericanEurasian Journal of Agricultural \& Environmental Science 12(7): 922-931.

Alam, M.M., Siwar, C., and Al-Amin, A.Q. 2010. Climate Change Adaptation Policy Guidelines for Agricultural Sector in Malaysia, Asian Journal of Environmental and Disaster Management 2(4): 463- 469.

Alam, M.M., Siwar, C., Jaafar, A.H. \& Talib, B. 2016c. Climatic Changes and Vulnerability of Household Food Availability in Malaysian East Coast Economic Region. Journal of Developing Areas 50(5): 143-155.

Alam, M.M., Siwar, C., Molla, R.I., Talib, B., and Mohd Ekhwan, T. 2012b. Paddy Farmers' Adaptation Practices to Climatic Vulnerabilities in Malaysia, Mitigation and Adaptation Strategies for Global Change 17(4): 415-423.

Alam, M.M., Siwar, C., Murad, M.W., and Mohd Ekhwan, T. 2011. Farm Level Assessment of Climate Change, Agriculture and Food Security Issues in Malaysia. World Applied Sciences Journal 14(3): 431-442.

Alam, M.M., Siwar, C., Talib, B., \& Wahid, A.N.M. 2017. Climatic Changes and Vulnerability of Household Food Accessibility in Malaysian East Coast Economic Region. International Journal of Climate Change Strategies and Management 9(3), 387-401.

Alam, M.M., Siwar, C., Wahid, A.N.M., \& Talib, B. 2016a. Food Security and Low-Income Households in the Malaysian East Coast Economic Region: An Empirical Analysis. Review of Urban \& Regional Development Studies 28(1): 2-15.

Alam, M.M., Talib, B., Siwar, C., \& Wahid, A.N.M. 2016b. Climate Change and Food Security of the Malayan East Coast Poor: A Path Modeling Approach. Journal of Economic Studies 43(3): 458-474.

Baer, R.D. \& Madrigal, L. 1993. Intra-household allocation of resources in larger and smaller Mexican households. Social Science \& Medicine 36: 305-310.

Béné, C. et al. 2016. Contribution of Fisheries and Aquaculture to Food Security and Poverty Reduction: Assessing the Current Evidence. World Development 79:177-196. 
Béné, C. et al. 2016. Is resilience a useful concept in the context of food security and nutrition programmes? Some conceptual and practical considerations. Food Security 8:123-38.

BP. 2018. $\mathrm{CO}_{2}$ emissions, https://www.bp.com/en/global/corporate/energyeconomics/statistical-review-of-world-energy/co2-emissions.html

Coates, J., Swindale, A. \& Bilinsky, P. 2007. Household food insecurity access scale (HFIAS) for measurement of household food access: indicator guide. Washington DC: Food and Nutrition Technical Assistance Project, Academy for Educational Development.

Coleman-Jensen, A., Gregory, C., \& Singh, A. 2015. Household Food Security in the United States in 2013. USDA-ERS Economic Research Report Number 173.

Cristofar S.P. \& Basiotis P.P. 1992. Dietary intakes and selected characteristics of women ages 19-50 years and their children ages 1-5 years by reported perception of food sufficiency. Journal of Nutrition Education 24:53-58.

Davies, S. 1996. Adaptable livelihoods. Coping with food insecurity in the Malian Sahel. London: MacMillan Press.

Devereux, S. 2001. Livelihood insecurity and social protection: A re-emerging issue in rural development. Development Policy Review 19(4): 507-19.

Dore, A.R., Adair, L.S., and Popkin, B.M. 2003. Low income Russian families adopt effective behavioral strategies to maintain dietary stability in times of economic crisis. Journal of Nutrition 133: 3469-3475.

Douxchamps, S., Van Wijk, M.T., Silvestri, S. et al. 2016. Linking agricultural adaptation strategies, food security and vulnerability: evidence from West Africa. Regional Environmental Change 16: 1305.

Easterling, W.E., Aggarwal, P.K., Batima, P., Brander, K.M., Erda, L., Howden, S.M., Kirilenko, A., Morton, J., Soussana, J-K., Schmidhuber, J. \& Tubiello , F.N. 2007. Food, Fibre and Forest Products. In Parry, M.L., Canziani, O.F., Palutikof, J.P., van der Linden, P.J. \& Hanson, C.E. (ed.). Climate change 2007: Impacts, adaptation and vulnerability. Contribution of working group II to the fourth assessment report of the intergovernmental panel on climate change, pp. 273-314. Cambridge: Cambridge University Press.

ECA. 2004. Land Tenure Systems and Their Impacts on Food Security and Sustainable Development in Africa. Addis Ababa: United Nations Economic Commission for Africa. 
ECER Master Plan. 2007. Economic Drives of the Region- Agriculture, East Coast Economic Region Development Council.

ECER Master Plan. 2008. Key Targets, East Coast Economic Region (ECER) Master Plan, East Coast Economic Region Development Council. (online) http://www.ecerdc.com.my/en/master-plan/success-factors/ (accessed on 18 July 2016)

Ellis, F. 1998. Survey article: Household strategies and rural livelihood diversification. Journal of Development Studies 35(1): 1-38.

EPU. 2017. Sustainable Development Goals, Voluntary National Review. Economic Planning Unit, Prime minister's Department, Malaysia.

Fabinyi, M., Dressler, W. H., Pido, M. D. 2017. Fish, Trade and Food Security: Moving beyond 'Availability' Discourse in Marine Conservation. Human Ecology 45(2): 177188.

FAO. 1997. Implications of Economic Policy for Food Security: A Training Manual. Training Materials for Agricultural Planning, 40. Rome: Food and Agriculture Organization of the United Nations.

FAO. 2003. Trade reforms and Food security: Conceptualizing the Linkages. Rome: Food and Agriculture Organization of the United Nations.

FAO. 2005. The State of Food Insecurity in the World 2005. Rome: Food and Agriculture Organization of the United Nations.

FAO. 2006. Food security, Policy Brief. Rome: Food and Agriculture Organization of the United Nations.

FAO. 2008. Climate Change and Food Security: A Framework Document, FAO interdepartmental working group on climate change, Rome: Food and Agriculture Organization of the United Nations.

FAO. 2009. Profile for Climate Change. Rome: Food and Agriculture Organization of the United Nation.

FAO. 2016. Climate Change and Food Security: Risks and Responses. Rome: Food and Agriculture Organization of the United Nation.

FAO. 2017. The State of Food Security and Nutrition in the World. Rome: Food and Agriculture Organization of the United Nation.

Fartahun, M., Berhane, Y., Wall, S., Byass, P., Hogberg, U. 2007. Women's involvement in household decision making and strengthening social capital are crucial factors for child survival in Ethiopia. Acta Paediatrica 96: 582-589. 
Farzana, F.D., Rahman, A.S., Sultana S., Raihan, M.J., Haque, M.A., Waid, J.L., et al. 2017. Coping strategies related to food insecurity at the household level in Bangladesh. PLoS ONE. 12(4): e0171411.

Field, A. 2000. Discovering Statistics using SPSS for Windows, London: Sage Publications.

Frankenberger, T. 1992. Indicators and Data Collection Methods for Assessing Household Food Security. In: Simon, M. \& Frankeberger, T.R. (eds.) Household Food Security: Concepts, Indicators, and Measurements: a technical Review, pp. 74-134. IFAD \& UNICEF, Rome \& New York.

Hammond, S. T., Brown, J. H., Burger, J. R., Flanagan, T. P., Fristoe, T. S. et al. 2015. Food Spoilage, Storage, and Transport: Implications for a Sustainable Future, BioScience, 65(8):758-768,

Hindin, M.J. 2006. Women's input in household decision and their nutritional status in three resource-constrained settings. Public Health Nutrition 9:485-493.

IEA. (2013). $\mathrm{CO}_{2}$ emissions from fuel combustion highlights. International Energy Agency (IEA).

IFAD. 2011. Rural poverty report 2011. New realities, new challenges: new opportunities for tomorrow's generation, International Fund for Agricultural Development (IFAD), Rome, Italy.

IPCC (Intergovernmental Panel on Climate Change). 2007. Climate Change 2007: The Physical Science Basis. Intergovernmental Panel on Climate Change. Cambridge University Press: Cambridge, U.K.

IPCC (Intergovernmental Panel on Climate Change). 2012. Managing the Risks of Extreme Events and Disasters to Advance Climate Change Adaptation. A Special Report of Working Groups I and II of the Cambridge University Press, Cambridge, UK and New York, NY, USA, 582 pp.

Lino, M. 1996. Income and spending of poor households with children. Family Economics and Nutrition Review 9: 2-13.

Lovendal, C.R. \& Knowles, M. 2006. Tomorrow's Hunger: A Framework for Analysing Vulnerability to Food Security, UNU- WIDER, Research Paper No. 2006/119.

Makinen, M., Waters, H., Rauch, M., Almagambetova, N., Bitran, R., Gilson, L., McIntyre, D., Pannarunothai, S., Prieto, A.L., Ubilla, G. and Ram, S. 2000. Inequalities in healthcare use and expenditures: Empirical data from eight developing countries and countries in transition. Bulletin of the World Health Organization 78(1): 55-65. 
Marchand, P. et al. 2016. Reserves and trade jointly determine exposure to food supply shocks. Environmental Research Letters 11: 095009.

Maxwell, D., Ahiadeke, C., Levin, C., Armar-Klemesu, M., Zakariah, A., and Lamptey, G.M. 1999. Alternative food security indicators - revisiting the frequency and severity of coping strategies. Food Policy 24: 411-429.

Myntti, C. 1993. Social determinants of child health in Yemen. Social Science \& Medicine 37: $233-240$.

Negatu, W. 2006. Determinants of small farm household food security: evidence from south Wollo, Ethiopia. Ethiopian Journal of Development Research 28(1): 1-29.

Nyariki, D.M. \& Wiggins, S. 1997. Household Food insecurity in Sub-Saharan Africa: Lesson from Kenya. British food journal 99(7): 249-262.

Olson, C.M., Rauschenbach, B.S., Frongillo, E.A. \& Kendall, A. 1997. Factors contributing to household food insecurity in rural upstate New York. Family Economics and Nutrition Review 10: 2-17.

Paul, B. 2013. Food Security in Malaysia Challenges and Opportunities for Malaysia of Present and in 2050 for maintaining foods security. University of Alberta. DOI: $10.13140 / 2.1 .2707 .7923$

Pfeiffer, J., Gloyd, S., Ramirez, L.L. 2001. Intra-household resource allocation and child growth in Mozambique: An ethnographic case-control study. Social Science \& Medicine 53: 83-97.

Piaseu, N. 2006. Factors affecting food insecurity among urban poor in Thailand. South African Journal of Clinical Nutrition 18: 156-160.

Pielke, R., Prins, G., Rayner, S. \& Sarewitz, D. 2007. Lifting the taboo on adaptation. Nature 445(7128): 597-598.

Qureshi, M. E., Dixon, J., Wood, M. 2015. Public policies for improving food and nutrition security at different scales. Food Security 7(2): 393-403.

Rezai, G., Shamsudin, M. N., Mohamme, Z. 2016. Urban Agriculture: A Way Forward to Food and Nutrition Security in Malaysia. Procedia - Social and Behavioral Sciences 216: 39-45.

Rose, D., Basiotis, P.P. \& Klein, B.W. 1995. Improving federal efforts to assess hunger and food insecurity. Food Review: 18-23.

Seekell, D., Carr, J., Dell'Angello, J., D’Odorcio, P., et al. 2017. Resilience in the global food system. Environmental Research Letters 12: 025010. 
Selamat, R., Ahmad, H., Lin, C. Z., Zainuddin, A. A., et al. 2015. Household food insecurity in Malaysia: findings from Malaysian Adults Nutrition Survey. Medical Journal of Malaysia 70 (S1): 11.

Shariff, Z.M., and Khor, G.L. 2008. Household food insecurity and coping strategies in a poor rural community in Malaysia. Nutrition Research and Practice 2(1): 26-34.

Siwar, C., Alam, M.M., Murad, M.W., and Al-Amin, A.Q. 2009. A Review of the Linkages between Climate Change, Agricultural Sustainability and Poverty in Malaysia, International Review of Business Research Papers 5(6): 309-321.

Smit, B. and Skinner, M.W. 2002. Adaptation Options in Agriculture to Climate Change: A Typology. Mitigation and Adaptation Strategies for Global Change 7: 85-114.

Smith, L. C. and Frankenberger, T. R. 2018. Does Resilience Capacity Reduce the Negative Impact of Shocks on Household Food Security? Evidence from the 2014 Floods in Northern Bangladesh. World Development 102:358-376.

Smith, P. J. 1998. Food Security and Political Stability in The Asia-Pacific Region, Conference Report, Honolulu: Asia-Pacific Center for Security Studies, September 11.

Stern, N. 2007. The Economics of Climate Change: The Stern Review. Cambridge University Press: Cambridge.

Studdert, L.J., Frongillo, E.A., and Valois, P. 2001. Household food insecurity was prevalent in Java during Indonesia's economic crisis. Journal of Nutrition 131: 2685-2691.

Thi, N.G.D., Kumar, G., Lin, C. Y. 2015. An overview of food waste management in developing countries: Current status and future perspective. Journal of Environmental Management. 157:220-229.

UN. 2015. The Millennium Development Goals Report 2015, United Nations, New York. http://www.un.org/millenniumgoals/2015_MDG_Report/pdf/MDG\%202015\%20rev $\% 20($ July\%201).pdf

UPM. 2017. Sekuriti Makanan di Malaysia, Fakulti Pertanian, Universiti Putra Malaysia, http://www.agri.upm.edu.my/article/food_security_in_malaysia-30913

Vaghefi, N., Mad Nasir Shamsudin, M. N., Alias Radam, A., and Rahim, K. A. 2016. Impact of climate change on food security in Malaysia: economic and policy adjustments for rice industry. Journal of Integrative Environmental Sciences 13(1): 19-35.

Webb, P., Braun, J.V. \& Yohannes. Y. 1992. Famine in Ethiopia - Policy Implication of the Coping Failure at National and Household Levels. Washington DC: International Food Policy Research Institute: Research Report 92. 
Yamane, T. 1967. Statistics: An introductory analysis. Edition 2. New York: Harper and Row.

Yohe, G.W., Lasco, R.D., Ahmad, Q.K., Arnell, N.W., Cohen, S.J., Hope, C., Janetos, A.C. \& Perez, R.T. 2007. Perspectives on climate change and sustainability. In Parry, M.L., Canziani, F., Palutikof, J.P., van der Linden, P.J. \& Hanson, C.E. (ed.). Climate change 2007: Impacts, adaptation and vulnerability, contribution of working group ii to the fourth assessment report of the intergovernmental panel on climate change. Cambridge, pp. 811-841. UK: Cambridge University Press.

Zalilah, M.S. 1998. Growth status determinants of school age children from primarily lowincome households in the urban area of Kuala Lumpur, Malaysia: A focus on intrahousehold factors. PH.D Dissertation, Michigan State University of USA.

Zalilah, M.S., and Ang, M. 2001. Assessment of food insecurity among low income households in Kuala Lumpur using the Radimer/ Cornell food insecurity instrument A validation study. Malaysian Journal of Nutrition 7: 15-32. 


\section{Appendix 1: List of variables}

Y1 Household food availability in the last one month, where available enough of the kinds of food you want to eat=5, enough but not always the kinds of food you want $=4$, sometimes not enough to eat $=3$, often not enough to eat $=2$, frequently stay hungry $=1$

Y2 Household status of food accessibility, where food secure access =4, mildly food insecure access $=3$, moderately food insecure access $=2$, severely food insecure access $=1$

$\mathrm{X} 1$ Education level, where illiterate $=1$, primary $=2$, secondary $=3$, higher $=4$

X2 Number of school going children

X3 Household poverty/economic status, where marginally non-poor=4, recent marginally non-poor $=3$, poor $=2$, hard core poor $=1$

$\mathrm{X} 4$ Spouse doing job, where yes $=1, \mathrm{no}=0$

X5 Head of household having supplementary job, where yes $=1, \mathrm{no}=0$

X6 Earning Ratio (Earning Family Member / Total Family Member) is coded in 1-5 scale based on equal value for every $20 \%$ ratio value, where $0-20 \%, 21-40 \%, 41-60 \%$, 6$80 \%$, and $81-100 \%$ are coded as $1,2,3,4,5$ respectively

X7 Household having any savings, where yes $=1, \mathrm{no}=0$

X8 Locality, where urban $=1$, rural $=0$

X9 Ownership of house, where yes $=1$, no $=0$

X10 Type of home, where wood made $=1$, mixed $=2$, brick $=3$

X11 Household having any transport for buying food, where yes $=1$, no $=0$

X12 Household buying bulk amount of food, where yes $=1, \mathrm{no}=0$

X13 Household having neat and clean kitchen and dining place, where yes $=1$, no $=0$

X14 Household having a hygienic sanitation facility, where strongly disagree $=1$, disagree $=2$, not sure $=3$, agree $=4$, strongly agree $=5$

X15 Household managing waste properly, where strongly disagree $=1$, disagree $=2$, not sure $=3$, agree $=4$, strongly agree $=5$

X16 Household having knowledge about maintaining nutrition level and having good sense of hygiene, where strongly disagree $=1$, disagree $=2$, not sure $=3$, agree $=4$, strongly agree $=5$

X17 Household having knowledge about taking precaution against dengue, malaria, etc., where strongly disagree $=1$, disagree $=2$, not sure $=3$, agree $=4$, strongly agree $=5$ 
X18 Dependency on common resources for cattle or livestock feeding, where very low=1, low $=2$, normal $=3$, high $=4$, very high $=5$

X19 Having the ability to adopt to non-climatic/general food insecurity (not caused by climatic issues), where strongly disagree $=1$, disagree $=2$, not sure $=3$, agree $=4$, strongly agree $=5$

X20 Changing food processing system for adaptation to non-climatic/general food insecurity, where yes $=1, \mathrm{no}=0$

X21 Changing food storing system for adaptation to non-climatic/general food insecurity, where yes $=1$, no $=0$

X22 Borrow money or foods for adaptation to non-climatic/general food insecurity, where yes $=1, \mathrm{no}=0$

X23 Reduce the number of meal for adaptation to non-climatic/general food insecurity, where yes $=1$, no $=0$

X24 Cook whatever food available for adaptation to non-climatic/general food insecurity, where yes $=1, \mathrm{no}=0$

X25 Reduce intake of food taken outside of home for adaptation to non-climatic/general food insecurity, where yes $=1, \mathrm{no}=0$

X26 Reduce food variation for adaptation to non-climatic/general food insecurity, where yes $=1$, no $=0$

X27 Reduce fruits and vegetables consumption for adaptation to non-climatic/general food insecurity, where yes $=1$, no $=0$

X28 Reduce spending on children education for adaptation to non-climatic/general food insecurity, where yes $=1$, no $=0$

X29 Take cheap medical treatment for adaptation to non-climatic/general food insecurity, where yes $=1$, no $=0$

X30 Take medical treatment only when situation get worse for adaptation to nonclimatic/general food insecurity, where yes $=1$, no $=0$

X31 Engage in a second job for adaptation to non-climatic/general food insecurity, where yes $=1$, no $=0$

X32 Migrate other places for adaptation to non-climatic/general food insecurity, where yes $=1$, no $=0$

X33 Having the ability to adapt to food insecurity causes by climatic issues, where strongly disagree $=1$, disagree $=2$, not sure $=3$, agree $=4$, strongly agree $=5$ 
X34 Changing food processing system for adaptation to climatic food insecurity, where yes $=1$, no $=0$

X35 Changing food storing system for adaptation to climatic food insecurity, where yes $=1$, no $=0$

X36 Borrow money or foods for adaptation to climatic food insecurity, where yes $=1, \mathrm{no}=0$

X37 Reduce the number of meal for adaptation to climatic food insecurity, where yes $=1$, no $=0$

X38 Cook whatever food available for adaptation to climatic food insecurity, where yes $=1$, no $=0$

X39 Reduce intake of food taken outside of home for adaptation to climatic food insecurity, where yes $=1$, no $=0$

X40 Reduce food variation for adaptation to climatic food insecurity, where yes $=1$, no $=0$

X41 Reduce fruits and vegetables consumption for adaptation to climatic food insecurity, where yes $=1, \mathrm{no}=0$

X42 Reduce spending on children education for adaptation to climatic food insecurity, where yes $=1$, no $=0$

X43 Take cheap treatment for adaptation to climatic food insecurity, where yes $=1$, no $=0$

X44 Take medical treatment only when situation get worse for adaptation to climatic food insecurity, where yes $=1, \mathrm{no}=0$

X45 Engage in a second job for adaptation to climatic food insecurity, where yes=1,no=0

X46 Migrate other places for adaptation to climatic food insecurity, where yes $=1$, no $=0$

X47 Overall external supports are needed to ensure food security, where strongly not needed $=1$, not needed $=2$, not sure $=3$, needed $=4$, strongly needed $=5$

X48 Supports are needed for income increasing program or incentive, where strongly not needed $=1$, not needed $=2$, not sure $=3$, needed $=4$, strongly needed $=5$

X49 Supports are needed for road and transport infrastructure improvement to ensure food distributions, where strongly not needed $=1$, not needed $=2$, not sure $=3$, needed $=4$, strongly needed $=5$

X50 Supports are needed for improving drinking water services, where strongly not needed $=1$, not needed $=2$, not sure $=3$, needed $=4$, strongly needed $=5$

X51 Supports are needed for improving health and medical services, where strongly not needed $=1$, not needed $=2$, not sure $=3$, needed $=4$, strongly needed $=5$

X52 Supports are needed for updating food distribution channel, where strongly not needed $=1$, not needed $=2$, not sure $=3$, needed $=4$, strongly needed $=5$ 
X53 Supports are needed for monitoring and adjustment in price at local market, where strongly not needed $=1$, not needed $=2$, not sure $=3$, needed $=4$, strongly needed $=5$

X54 Supports are needed for improving agriculture and other agency services, where strongly not needed $=1$, not needed $=2$, not sure $=3$, needed $=4$, strongly needed $=5$

X55 Supports are needed for climatic related subsidies or rationing for food, where strongly not needed $=1$, not needed $=2$, not sure $=3$, needed $=4$, strongly needed $=5$

X56 Supports are needed for food aids for emergency time, where strongly not needed=1, not needed $=2$, not sure $=3$, needed $=4$, strongly needed $=5$

X57 Supports are needed for providing emergency services for disaster time, where strongly not needed $=1$, not needed $=2$, not sure $=3$, needed $=4$, strongly needed $=5$

X58 Supports are needed for special food distribution arrangements in emergency time, where strongly not needed $=1$, not needed $=2$, not sure $=3$, needed $=4$, strongly needed $=5$ 
Appendix 2: Correlation among the variables of household resilience factors

\begin{tabular}{|c|c|c|c|c|c|c|c|c|c|c|c|c|c|c|c|c|c|}
\hline & $\mathrm{X} 1$ & $\mathrm{X} 2$ & $\mathrm{X} 3$ & $\mathrm{X} 4$ & $\mathrm{X} 5$ & X6 & $\mathrm{X} 7$ & $\mathrm{X} 8$ & X9 & $\mathrm{X} 10$ & $\mathrm{X} 11$ & $\mathrm{X} 12$ & $\mathrm{X} 13$ & X14 & $\mathrm{X} 15$ & $\mathrm{X} 16$ & $\mathrm{X} 17$ \\
\hline $\bar{X} 2$ & $.263^{* *}$ & & & & & & & & & & & & & & & & \\
\hline X3 & -0.056 & $-.136^{* *}$ & & & & & & & & & & & & & & & \\
\hline $\mathrm{X} 4$ & 0.004 & $.146^{* *}$ & 0.037 & & & & & & & & & & & & & & \\
\hline$\times 5$ & 0.071 & 0.074 & -0.091 & -0.032 & & & & & & & & & & & & & \\
\hline X6 & $-.206^{* *}$ & $-.390^{* *}$ & $.124^{* *}$ & -0.047 & -0.091 & & & & & & & & & & & & \\
\hline $\mathrm{X} 7$ & 0.082 & $-.137^{* *}$ & $.144^{* *}$ & 0.021 & 0.021 & $.122^{* *}$ & & & & & & & & & & & \\
\hline X8 & 0.015 & 0.03 & 0.048 & 0.018 & -0.067 & 0.009 & $.095^{*}$ & & & & & & & & & & \\
\hline X9 & -0.057 & -0.071 & 0.023 & $-.095^{*}$ & -0.01 & 0.039 & 0.025 & -0.01 & & & & & & & & & \\
\hline $\mathrm{X} 10$ & -0.013 & 0.013 & $.105^{*}$ & 0.075 & -0.023 & 0.016 & 0.067 & 0.045 & -0.031 & & & & & & & & \\
\hline $\mathrm{X} 11$ & $.106^{*}$ & $.157^{* *}$ & -0.02 & 0.071 & 0.008 & $-.155^{* *}$ & -0.009 & -0.067 & 0.008 & $.100^{*}$ & & & & & & & \\
\hline $\mathrm{X} 12$ & 0.082 & $.150^{* *}$ & 0.091 & 0.046 & -0.084 & $-.109^{*}$ & 0.016 & 0.083 & -0.023 & $.130^{* * *}$ & $.276^{* *}$ & & & & & & \\
\hline X13 & 0.004 & 0.001 & -0.003 & -0.011 & -0.014 & -0.085 & 0.01 & $.252^{* *}$ & 0.007 & $.103^{*}$ & 0.018 & $.183^{* *}$ & & & & & \\
\hline X14 & 0.067 & 0.005 & 0.03 & -0.084 & 0.083 & 0.016 & $.142^{* *}$ & 0.041 & 0.019 & 0.033 & 0.059 & $.139^{* *}$ & 0.058 & & & & \\
\hline X15 & 0.034 & -0.001 & 0.022 & -0.041 & 0.03 & 0.018 & 0.083 & 0.053 & 0.041 & -0.005 & $.179^{* *}$ & 0.088 & -0.027 & $.569^{* *}$ & & & \\
\hline X16 & 0.03 & -0.023 & -0.054 & 0.005 & 0.082 & -0.052 & 0.055 & $-.143^{* *}$ & -0.012 & -0.041 & 0.088 & 0.044 & -0.021 & $.313^{* *}$ & $.417^{* *}$ & & \\
\hline $\mathrm{X} 17$ & 0.024 & -0.044 & 0.008 & -0.091 & 0.029 & 0.018 & 0.072 & 0.01 & 0.057 & -0.072 & $.132 * *$ & $.131 * *$ & -0.011 & $.519 * *$ & $.629 * *$ & $.320 * *$ & \\
\hline X18 & 0.017 & -0.032 & $-.095 *$ & -0.068 & -0.051 & -0.049 & 0.005 & -0.049 & -0.017 & 0.083 & 0.033 & -0.035 & -0.039 & 0.014 & -0.033 & $.171 * *$ & -0.051 \\
\hline Y1 & -0.052 & $-.350 * *$ & $.292 * *$ & 0.005 & -0.081 & $.247 * *$ & $.316^{* *}$ & 0.021 & 0.047 & 0.056 & $.092 *$ & 0.065 & 0.03 & $.150 * *$ & $.216 * *$ & $.135^{* *}$ & $.128 * *$ \\
\hline Y2 & -0.081 & $-.351^{* *}$ & $.224^{* *}$ & 0.024 & -0.078 & $.243^{* *}$ & $.296^{* *}$ & 0.045 & 0.079 & 0.052 & $.098^{*}$ & 0.029 & 0.041 & $.132^{* *}$ & $.219^{* * *}$ & $.144^{* *}$ & $.108^{*}$ \\
\hline
\end{tabular}

Note: $*$ and $* *$ indicate correlations are significant at the 0.05 and 0.01 level (2-tailed) 


\section{Appendix 3: Correlation among the variables of household adaptation approaches}

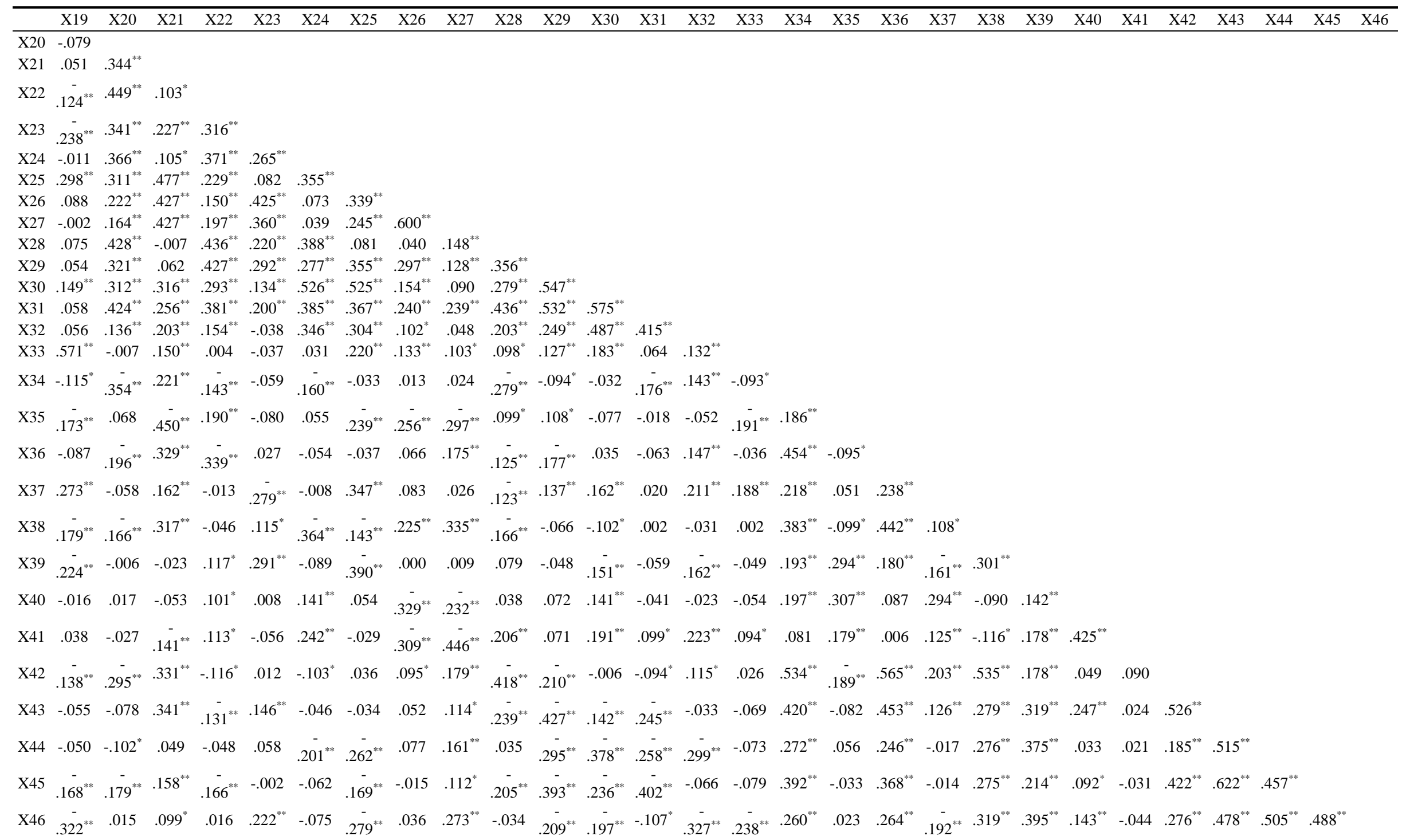




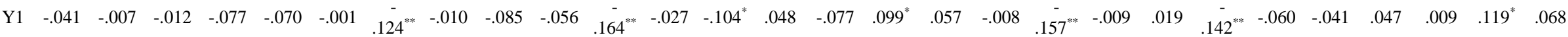
$\begin{array}{llllllllllllllllllllllllllllllllllll}\text { Y2 } & -.021 & -.022 & -.007 & -.095^{*} & -.068 & .039 & -.117^{*} & -.001 & -.084 & -.037 & -164^{* * *} & -.003 & -.096^{*} & .101^{*} & -.022 & .054 & -.028 & -.003 & -167^{* *} & .001 & .004 & - & -178^{* *} & -.031 & -.020 & .042 & .002 & .112^{*} & .038\end{array}$ $*$ and $* *$ indicae correlations are significant at the 0.05 and 0.01 level (2-tailed)

\section{Appendix 4: Correlation among the variables of expected supports}

\begin{tabular}{|c|c|c|c|c|c|c|c|c|c|c|c|c|c|}
\hline & X47 & $\mathrm{X} 48$ & $\mathrm{X} 49$ & $\mathrm{X} 50$ & X51 & X52 & X53 & $\mathrm{X} 54$ & $\mathrm{X55}$ & X56 & X57 & X58 & Y1 \\
\hline $\mathrm{X} 48$ & $.554^{* *}$ & & & & & & & & & & & & \\
\hline X49 & $.366^{* *}$ & $.635^{* *}$ & & & & & & & & & & & \\
\hline X50 & $.373^{* *}$ & $.578^{* *}$ & $.628^{* *}$ & & & & & & & & & & \\
\hline X51 & $.434^{* *}$ & $.605^{* *}$ & $.634^{* *}$ & $.748^{* *}$ & & & & & & & & & \\
\hline X52 & $.296^{* *}$ & $.569^{* *}$ & $.647^{* *}$ & $.564^{* *}$ & $.613^{* *}$ & & & & & & & & \\
\hline X53 & $.333^{* *}$ & $.526^{* *}$ & $.586^{* *}$ & $.496^{* *}$ & $.526^{* *}$ & $.794^{* *}$ & & & & & & & \\
\hline X54 & $.366^{* *}$ & $.482^{* *}$ & $.541^{* *}$ & $.545^{* *}$ & $.391^{* *}$ & $.559^{* *}$ & $.578^{* *}$ & & & & & & \\
\hline X55 & $.624^{* *}$ & $.415^{* *}$ & $.302^{* *}$ & $.345^{* *}$ & $.270^{* *}$ & $.224^{* *}$ & $.268^{* *}$ & $.384^{* *}$ & & & & & \\
\hline X56 & $.447^{* *}$ & $.623^{* *}$ & $.560^{* *}$ & $.494^{* *}$ & $.680^{* *}$ & $.426^{* *}$ & $.401^{* *}$ & $.206^{* *}$ & $.388^{* *}$ & & & & \\
\hline X57 & $.275^{* *}$ & $.476^{* * *}$ & $.499^{* * *}$ & $.505^{* *}$ & $.642^{* * *}$ & $.670^{* * *}$ & $.691^{* * *}$ & $.360^{* *}$ & $.171^{* * *}$ & $.569^{* * *}$ & & & \\
\hline X58 & $.330^{* *}$ & $.580^{* *}$ & $.627^{* *}$ & $.573^{* *}$ & $.582^{* *}$ & $.755^{* *}$ & $.760^{* *}$ & $.589^{* *}$ & $.324^{* *}$ & $.506^{* *}$ & $.780^{* *}$ & & \\
\hline Y1 & $.112^{*}$ & 0.011 & -0.07 & -0.05 & -0.09 & $-.106^{*}$ & $-.112^{*}$ & -0.04 & $.095^{*}$ & -0.01 & -0.089 & $-.125^{* *}$ & \\
\hline $\mathrm{Y} 2$ & 0.089 & -0.01 & -0.06 & -0.06 & $-.100^{*}$ & $-.110^{*}$ & $-.124^{* *}$ & -0.03 & 0.066 & -0.02 & $-.094^{*}$ & $-.133^{* *}$ & $.942^{* *}$ \\
\hline
\end{tabular}

